\title{
Creeping Discharge and Light Emission Characteristics on Plane Electrodes with Stripe Backside Electrode
}

\author{
Takaaki Tohara Student Member (University of Hyogo) \\ Hideki Ueno Member (University of Hyogo) \\ Hiroshi Nakayama Member (University of Hyogo)
}

Keywords : creeping discharge, Backside electrode, Light emission, Ne gas

Suppression of surface discharge is one of important technologies on power apparatuses have been investigated intensively. Recently, surface discharge control technology has been focused from practical applications such as ozonizer, NOx reactors, light source or display. In the present work, fundamental creeping discharge and light emission characteristics for a configuration with two plane electrodes on the dielectric material with a flat cable backside electrode in $\mathrm{Ne}$ gas under ac voltage application have been studied.

Figure 1 shows a schematic illustration of the electrode configuration in this work. A borosilicate glass was used as a dielectric material. Two copper plates with $21 \mathrm{~mm}$ in width as a HV electrode and a grounded electrode were placed on the glass plate and the distance between them was set at $10 \mathrm{~mm}$. The backside electrode was attached on another side of the glass plate.A flat cable with width of $X(1.0-21 \mathrm{~mm})$ The flat cable was composed by the rectangular conductors with $0.7 \mathrm{~mm}$ in width that are aligned with a $1.0 \mathrm{~mm}$-pitch and laminated by polyester.

Figure 2 shows gas pressure dependence of discharge inception voltage for various backside electrode widths in comparison with that without backside electrode. In the case of the configuration without backside electrode, discharge inception voltage increased monotonically with increasing gas pressure. On the configuration with a backside electrode, the discharge inception voltage decreased when the backside electrode width increased. In addition, it tended to saturate at gas pressure higher than $30 \mathrm{kPa}$. Observation of discharge using imag-intensified CCD camara have been also carried out. Discharge images for the electrode width of $10.5 \mathrm{~mm}$ are given in Fig.3. Discharge developed along the dielectric plate surface at higher than $30 \mathrm{kPa}$, however, discharge grew in the gaseous space apart from the surface under the pressure of $10 \mathrm{kPa}$.

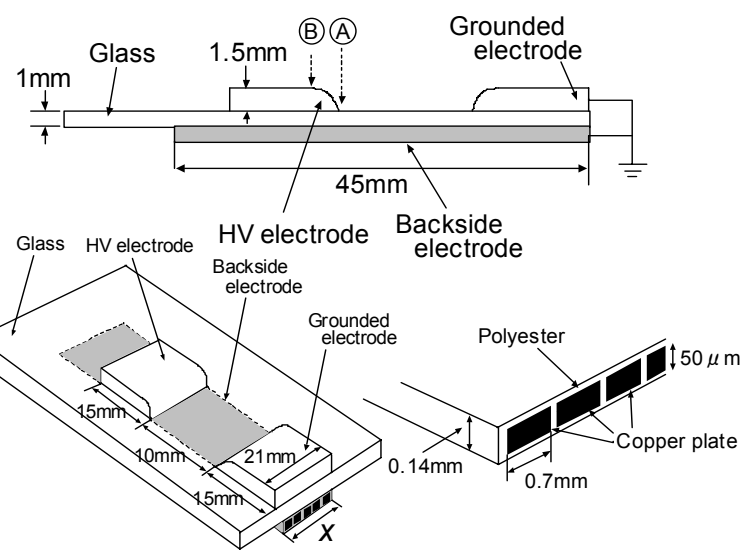

Fig. 1. Electrode configuration
Figure 4 shows light emission spectra of discharge for the relatively strong light emission was observed in the range of $580 \mathrm{~nm} \sim 730 \mathrm{~nm}$. Most of them were associated with the emission processes of Ne. Especially, these light emissions should be originated from the transition from $3 p$ to $3 \mathrm{~s}$ of Ne. Furthermore, the emission intensity was affected by the gas pressure and backside electrode width at almost same applied voltage.

In conclusion, these facts suggest that the effect of the backside electrode strongly depends on their width and gas pressure.

A part of this work was supported by a Grant-in-Aid for Scientific Research (C) on JSPS (No.16560250).

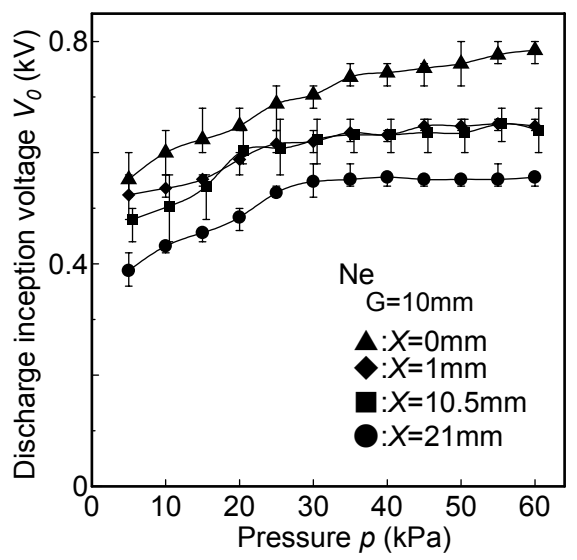

Fig. 2. Gas pressure dependence of discharge inception voltage.

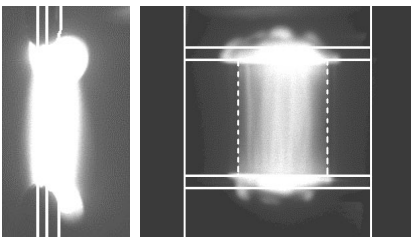

$p=30 \mathrm{kPa} \quad V=0.60 \mathrm{kV}$

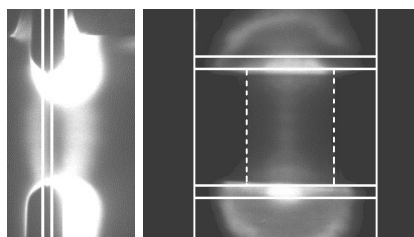

$p=10 \mathrm{kPa} \quad V=0.36 \mathrm{kV}$

Side

Fig. 3 Picture of electrical discharge $(X=10.5 \mathrm{~mm})$
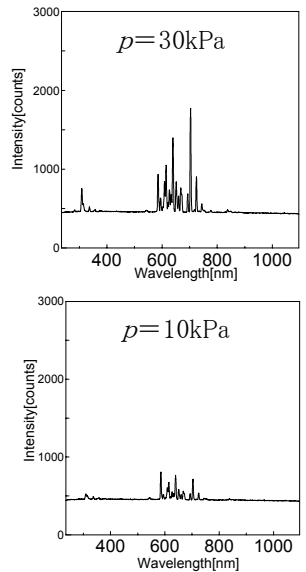

Fig. 4 Spectrum of electrical discharge $(X=10.5 \mathrm{~mm})$ 


\title{
ストライプ状背後電極を有した平板電極間の沿面放電と発光
}

\author{
学生員 東原 孝明* 正 員 上野 秀樹* \\ 正員 中山 博史*
}

\section{Creeping Discharge and Light Emission Characteristics on Plane Electrodes with Stripe Backside Electrode}

Takaaki Tohara*, Student Member, Hideki Ueno*, Member, Hiroshi Nakayama*, Member

\begin{abstract}
Creeping discharge and light emission characteristics in $\mathrm{Ne}$ gas for the configuration with plane electrodes on the dielectric plate with a stripe backside electrode have been investigated. In the case of the configuration without backside electrode, discharge inception voltage increased monotonically with increasing gas pressure. For the configuration with a backside electrode discharge inception voltage decreased when the backside electrode became wide. Moreover, it tended to saturate over $30 \mathrm{kPa}$ for the configuration with a backside electrode. By observations of discharge using image-intensified CCD camera, discharge developed along the dielectric plane surface at $30 \mathrm{kPa}$ on $60 \mathrm{kPa}$, on the other hand, discharge grew in the gaseous space away from dielectric surface. These facts suggest that the effect of backside electrode strongly depends on the their width and gas pressure.
\end{abstract}

キーワード : 沿面放電, 背後電極, 発光, $\mathrm{Ne}$ ガス

Keywords : creeping discharge, backside electrode, light emission, $\mathrm{Ne}$ gas

\section{1. はじめに}

沿面放電は異種の誘電体の境界面に沿って発生, 進展す る放電現象である ${ }^{(1)}$ 。誘電体表面上の沿面放電は, 気中放電 に比べて進展しやすく電力機器や電力設備において絶縁破 壊を引き起こす原因と考えられている。それゆえ, 電力機 器や電子素子の絶縁設計上, 沿面放電を制御することが重 要なポイントとなる。

絶縁物裏面の背後電極の存在によって, 沿面放電が進展 しやすくなる (2) (4)ことから沿面放電の発生と進展を如何に して抑制するのかを目的とした研究は数多く行われてきた (5)。一方, 沿面放電の積極的な利用・応用を目的とした研究 には，NOx 等の環境污染物質の除去装置やオゾナイザ等が 挙げられるが(6)，さらなる応用の拡大が期待できる。

ところで，沿面放電と同様に誘電体が介在した放電であ るバリア放電の応用として PDP（プラズマディスプレイ） が挙げられる。カラーPDP はガス放電による発光を利用し た表示デバイスであり，放電によって放射される紫外線が 各放電セル内壁に塗布された蛍光体を発光させる(7)。PDP の放電ガスには安定で効率的なガスとして, 希ガスが使わ

\footnotetext{
* 兵庫県立大学大学院工学研究科電気系工学専攻

干671-2201 姫路市書写 2167

Department of Electrical Engineering and Computer Sciences,

Graduate School of Engineering, University of Hyogo

2167 Shosha, Himeji 671-2201
}

れる。この中でもっとも長波長の Xe は, 単体では放電電圧 が高いため, $\mathrm{He} や \mathrm{Ne}$ を母体ガスとした混合ガスにして放 電電圧を下げている( ${ }^{(8)}$ 。また最近では, 沿面放電の発光を利 用した表示素子の提案もされている(9)(10)。

沿面放電に関する研究は古くから数多くされているが, 沿面放電による発光, とりわけ発光領域や空間については 不明な点も多く残されている。また, 沿面放電は背後電極 の影響を大きく受けるので, 発光領域に及ぼす背後電極の 影響も明らかにする必要があると考えられる。これまでの 沿面放電の基礎的な特性の解明には, 多くの場合背後電極 として面状のものや線状のものが用いられてきた。しかし, オゾナイザーや発光を利用した素子に沿面放電を応用する 場合，櫛形電極やマトリクス電極が用いられると考えられ， それによりストライプ状に配置された導体が背後電極とな る可能性もある。しかし, 複数の導体で構成される背後電 極を持つ電極系における沿面放電についてはほとんど調べ られていない。

そこで本実験では，ストライプ状背後電極を有する誘電 体上に配置した平板電極間において交流電圧を印加したと きに発生する沿面放電の基礎特性を調べた。特に希ガスで 最も放電開始電圧の低い $\mathrm{Ne}$ ガス中での放電開始電圧, 放電 発光の様子, 放電発光のスペクトルの測定を行なった。得 られた放電発生点, 放電路, 発光強度等の結果と背後電極 
の幅やストライプ状の導体位置との関係について検討を 行った。

\section{2. 実験方法}

〈2·1〉電極構成本実験で用いた電極構成図を図 1 に示す。高圧電極(HV electrode), アース電極(Grounded electrode)にはそれぞれ $15 \mathrm{~mm} \times 21 \mathrm{~mm}$, 曲率半径 $884 \mu \mathrm{m}$ の銅 製平板を使用した。電極間距離は $10 \mathrm{~mm}$ 一定である。その 下部に, 誘電体として $76 \mathrm{~mm} \times 52 \mathrm{~mm}$, 厚さ $1 \mathrm{~mm}$ のエタノー ルで洗浄, 除電された嗍硅酸ガラスを配置した。硼硅酸ガ ラスは表面抵抗率 $\rho_{\mathrm{s}}=10^{11} \Omega$, 体積抵抗率 $\rho_{\mathrm{v}}=10^{12} \Omega \cdot \mathrm{m}$, 比誘 電率 7.0 である。その下に背後電極として, $45 \mathrm{~mm} \times 0.7 \mathrm{~mm}$ $\times 50 \mu \mathrm{m}$ の軟銅箔をポリエステル(比誘電率 : 約 3.3)で絶縁し たフラットケーブル(導体幅 $0.7 \mathrm{~mm}$, ピッチ $1.0 \mathrm{~mm}$ )を配置し 接地した。背後電極幅 $X$ が $1 \mathrm{~mm}$ (導体数: 1 本), $10.5 \mathrm{~mm}$ (導体 数:9 本), $21 \mathrm{~mm}$ (導体数: 18 本) と背後電極がない場合 $X=0 \mathrm{~mm}$ において実験を行った。背後電極はほぼ全体を絶縁テープ で覆いガラスとの間に隙間が生じないように貼付けた。高 圧電極はアクリル樹脂製クリップでガラスと挟込むととも に，ネジでガラスに密着するように固定した。アース電極 もクリップでガラスに密着固定した。

$\langle 2 \cdot 2\rangle$ 実験回路図 図 2 に実験回路図を示す。印加 電圧は交流電圧 $(60 \mathrm{~Hz})$ を使用し, トランス, 保護抵抗を介し

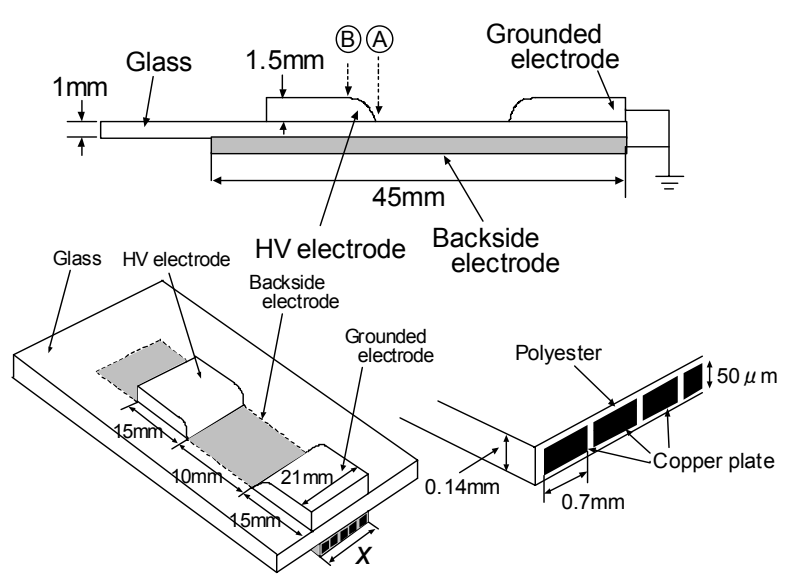

Fig. 1. Electrode configuration

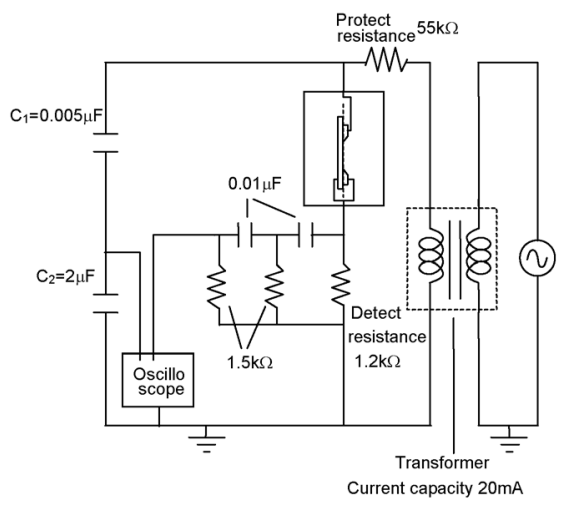

Fig. 2. Diagram of experimental circuit
て, 放電部の電圧を並列に接続した分圧用コンデンサ $\mathrm{C}_{1}$, $\mathrm{C}_{2}$ を用いデジタルオシロスコープにより測定した。電流は 放電部に直列に検出抵抗(1.2k $\Omega$ )を接続し, 電源周波数成分 を除くためハイパスフィルタ(遮断周波数: $1 \mathrm{kHz}$ )を介して測 定した。

〈2·3〉放電発光の撮影及び観測 放電時の発光の様 子は黄銅製真空容器に設けられた観測空(石英ガラス)を通 じて行なった。一眼レフカメラ(AE-1, キャノン)及び高速 ゲートイメージインテンシファイアを取り付けた CCD カメ ラ(C4346, 浜松ホトニクス)を用いて撮影した。一眼レフカ メラの場合, 露光時間は $1 \mathrm{~s}$ とした CCD カメラの場合は, 図 3 のように露光時間 $1 \mathrm{~ms}$ とし, 正極, 負極の最後を $0.35 \mathrm{~ms}$ ずつ(斜線部)除いて 16 分割して撮影した。CH1 が電流波形, $\mathrm{CH} 2$ が電圧波形, $\mathrm{CH} 3$ はカメラのシャッター開閉用トリガ パルスを示す。トリガのパルス幅が露光時間 $(1 \mathrm{~ms})$ である。 印加電圧が正から負, または負から正に変るときにオシロ スコープよりトリガを発生させ, ディレイジェネレータ (DG535，Stanford Research Systems)を通して，ディレイ時間 を $1 \mathrm{~ms}$ づつ変化させて撮影した。ディレイ時間 $0 \mathrm{~ms}$ とした ときの印加電圧極性反転から実際にシャッター開までの遅 れ時間は 0.2 0.3 $\mu \mathrm{s}$ である。電圧波形に付けた各番号の時間 内での放電発生・進展による発光を撮影した。放電の発光ス ペクトルの観測は光ファイバ(コア径: $400 \mu \mathrm{m}$, 受光角: $25.5^{\circ}$ ) を介して分光器(SA-100, 株ラムダビジョン)によった。受光 時間 $100 \mathrm{~ms}$, 計測積算平均 10 回に設定し各条件 5 回測定を 行った。

\section{3. 実験結果}

〈3.1〉＼cjkstart放電開始電圧＼cjkstart背後電極およびガス圧が放電 開始電圧にどのような影響を及ぼすか調べた。背後電極幅 $X$ が $0 \mathrm{~mm}, 1 \mathrm{~mm}, 10.5 \mathrm{~mm}, 21 \mathrm{~mm}$ における放電開始電圧のガ ス圧依存性を図 4 に示す。放電開始電圧の測定は 10 回行い, その平均值と最大值, 最小值を図に示している。なお, 用 いたガラスの表面電荷減衰の時定数は $67 \mathrm{~s}$ であり, 前測定時 の放電による残留電荷の影響を避けるため, 時定数以上の 間隔をあけて測定を行った。

背後電極幅 $X=1 \mathrm{~mm}, 10.5 \mathrm{~mm}, 21 \mathrm{~mm}$ のいずれの条件にお いても, $5 \mathrm{kPa} \sim 20 \mathrm{kPa}$ の範囲でガス圧の増加に伴い放電開始 電圧も上昇するが， $30 \mathrm{kPa}$ あたりから上昇は緩やかとなり， 約 $40 \mathrm{kPa} \sim 60 \mathrm{kPa}$ においてはほぼ一定の放電開始電圧とな

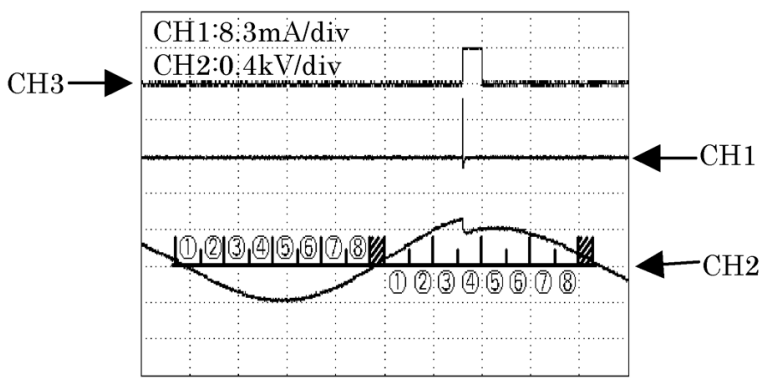

Fig. 3. Appearance of taking a picture 
る。 $X=1 \mathrm{~mm}, 10.5 \mathrm{~mm}$ のとき $0.65 \mathrm{kV}$ で, $X=21 \mathrm{~mm}$ のとき $0.55 \mathrm{kV}$ でそれぞれ飽和した。 $X=1 \mathrm{~mm}, 10.5 \mathrm{~mm}$ はほぼ同じ電圧であ るが $X=21 \mathrm{~mm}$ の場合, 背後電極を広げたことで放電開始電 圧は約 $0.1 \mathrm{kV}$ 低下した。

一方, 背後電極のない $X=0 \mathrm{~mm}$ の場合, 他の背後電極幅 と同様に $5 \mathrm{kPa} \sim 20 \mathrm{kPa}$ あたりまでガス圧に比例して放電開 始電圧も上昇し， $30 \mathrm{kPa}$ あたりから上昇は緩やかとなるが， 飽和には至らなかった。

〈3·2〉種々の条件下での放電の挙動 次に, 背後電 極幅の違いによる放電挙動を調べるため, 放電の様子を一 眼レフカメラで撮影した。

$X=1 \mathrm{~mm}, 10.5 \mathrm{~mm}$ について, ガス圧を $10 \mathrm{kPa}, 30 \mathrm{kPa}, 60 \mathrm{kPa}$ と変化させたときの一眼レフカメラで撮影した放電の様子 を図 5 に示す。図 5(a)は $X=1 \mathrm{~mm}$, 図 5(b)は $X=10.5 \mathrm{~mm}$ にお ける各ガス圧の放電の様子である。カメラの露光時間は全 て 1s である。右が正面から見た放電の様子で, 左が同じ条 件で撮影した側面から見た放電の様子である。放電の写真 の上側が高圧電極，下側がアース電極を示す。図中の各電 極上の二本の線は図 1 に示したように，電極端 (A) と丸みの ある電極位置 Bを示す。また背後電極の位置を点線で示す。

まず $10 \mathrm{kPa}$ での正面からの放電挙動を見ると, どちらの 背後電極幅も電極間に広がった淡い放電が確認でき，放電 幅は背後電極幅と同じであった。また，側面から見た放電 は, 誘電体に沿った放電ではなく誘電体から離れ, ガス中 で弧を描くような発光となった。

一方 $30 \mathrm{kPa}, 60 \mathrm{kPa}$ の正面からの放電挙動をみると, フィ ラメント状の放電路が確認できる。 $X=1 \mathrm{~mm}$ では一見フィラ メント状の発光には見えないが, 発光の明るさと $X=10.5 \mathrm{~mm}$ の結果から, $30 \mathrm{kPa}$ と $60 \mathrm{kPa}$ ではフィラメント状の放電路が 重なり合って形成されていることがわかる。どの放電も必 ず背後電極幅内にみられ, 背後電極幅以上の幅を持つ放電 は見られない。側面から見た放電は，10kPa とは異なり図 5(a), 図 5(b)ともにガス圧が高くなると空閒への広がりは押 さえられてより沿面に沿う様になっている。

次に一眼レフカメラを用いた撮影では感度の関係で露光

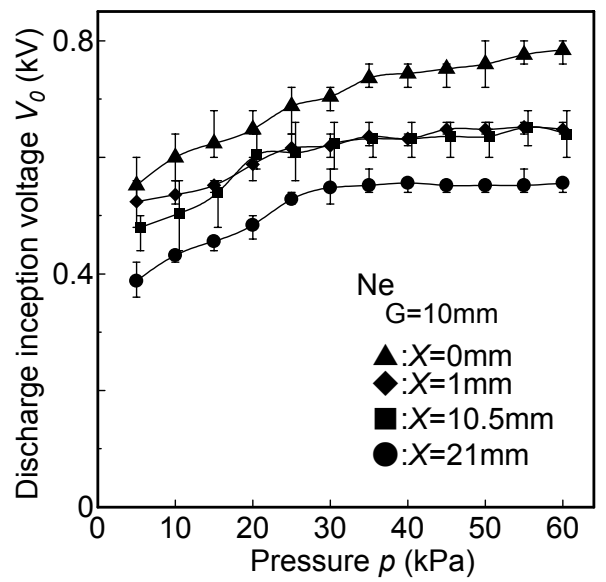

Fig. 4. Gas pressure dependence of discharge inception voltage
時間を $1 \mathrm{~s}$ と長くしたため, 詳細な放電挙動は観測できない。 そこで露光時間を $1 \mathrm{~ms}$ として CCD カメラを用いて放電挙動 を観測した。撮影はガス圧 $10 \mathrm{kPa}, 30 \mathrm{kPa}$ ，背後電極幅 $1 \mathrm{~mm}$, $10.5 \mathrm{~mm}$ について, 正面方向から行った。電極に交流電圧を 印加すると, まず図 6(a)のように交流電圧の正極, または負 極どちらか一方の極性から放電を開始した。さらに図 6(b) に示した過電圧印加時には両極性において放電が生じ電圧 降下が見られた。この時の電流は正極性で約 $32 \mathrm{~mA}$, 負極性 で約 $36 \mathrm{~mA}$ と大きな差は見られない。また, ガス圧を変え た場合も同様の電流波形となった。すなわち, 印加電圧が 最大值付近では, 複数の放電電流は観測されず, 1 本の鋭い 放電電流ピークが観測された。本研究ではこの二つの放電 の様子を撮影し, 背後電極幅, ガス圧の変化による放電の 違いについて検討を行った。

図 7 は $X=10.5 \mathrm{~mm}, \quad p=10 \mathrm{kPa}$ の放電挙動である。図 7(a) は発光が強く放電挙動が観測しにくい。色ガラス(HOYA ND25), 紫外透過可視吸収フィルタ(吸収波長域:400 650nm, HOYA U330)を用いることにより, 図 7(b)に示す様に放電の
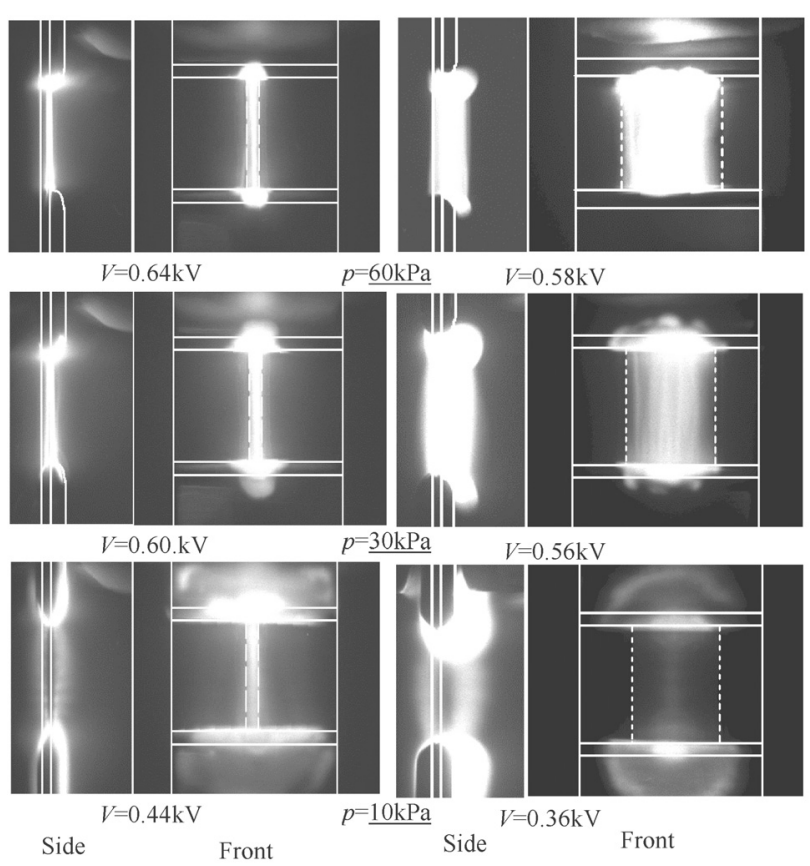

(a) $X=1 \mathrm{~mm}$

(b) $X=10.5 \mathrm{~mm}$

Fig. 5. Pictures of electrical discharge with single-lens reflex camera $(X=1 \mathrm{~mm}, 10.5 \mathrm{~mm})$

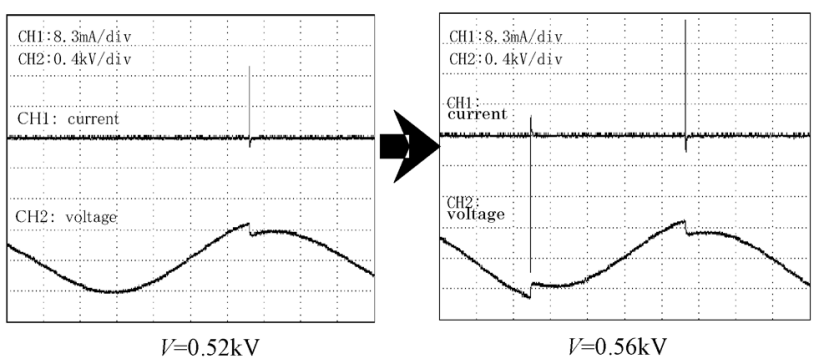

(a) Discharge inception

(b) Overvoltage

Fig. 6. Waveforms of applied voltage and current 
様子が明瞭に撮影でき, 以降の撮影はすべてこれらのフィ ルタを通して行った。

$\mathrm{CCD}$ で撮影した背後電極幅 $X=10.5 \mathrm{~mm}, \quad p=10 \mathrm{kPa}$ での放 電の様子を図 8 に示す。まず $V=0.72 \mathrm{kV}$ で負極(5)において 放電が生じ, さらに電圧を $V=0.76 \mathrm{kV}$ に上昇させると正極 (4), 負極(4)の両方において淡い放電が生じた。どちらの場 合もそれ以外のポイントにおいて放電は確認できない。

また，放電はつねに同じポイントでは起こらず 正極，負 極共に(3)，(4)，(5)において顕著に見られた。放電の場所も 常に同じ位置からではないが，必ず背後電極の範囲内で生 じた。

$\mathrm{CCD}$ で撮影した背後電極幅 $X=1 \mathrm{~mm}, 10 \mathrm{kPa}$ での放電の様

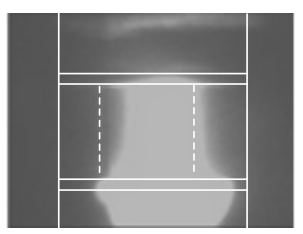

(a) Without filter

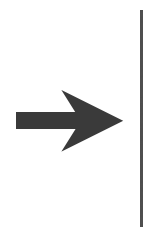

Fig. 7. Pictures of electrical discharge with CCD camera $(X=10.5 \mathrm{~mm}, p=10 \mathrm{kPa})$

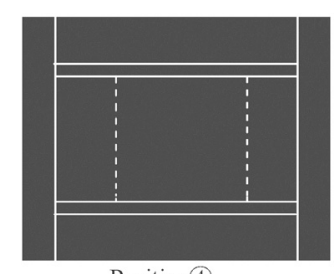

Positive (4)

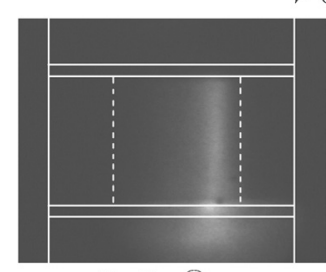

Positive(4)

$V=0.76 \mathrm{kV}$

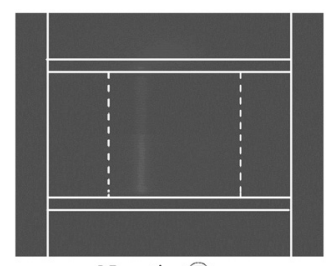

Negative(5)

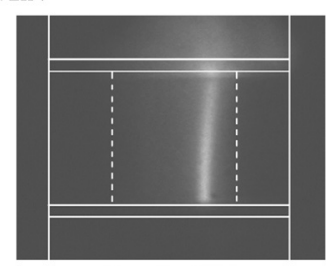

Negative(4)

Fig. 8. Picture of discharge $(X=10.5 \mathrm{~mm}, p=10 \mathrm{kPa})$

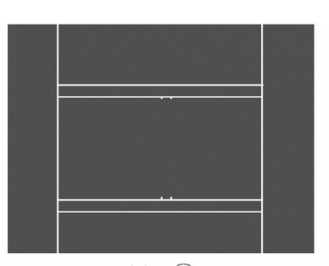

Positive(4)

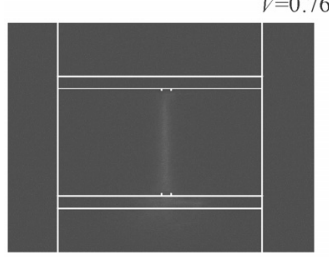

Positive (4)

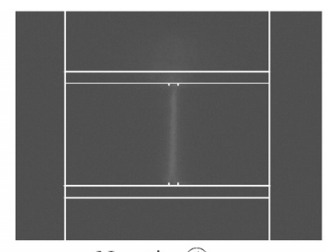

Negative(4)

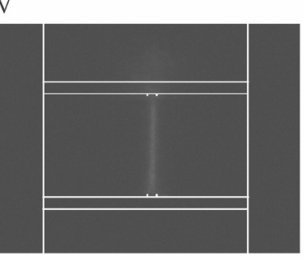

Negative(3)
Fig. 9. Picture of discharge $(X=1 \mathrm{~mm}, p=10 \mathrm{kPa})$

子を図 9 に示す。ここでは，放電の様子が見やすいように， 背後電極幅を示す点線は消してある。この場合， $V=0.76 \mathrm{kV}$ で負極(4)において放電が生じさらに電圧を $V=0.84 \mathrm{kV}$ にあげ ることで正極(4), 負極(3の両方において淡い放電が生じた。 $X=1 \mathrm{~mm}$ のときも放電は必ず背後電極幅内で生じた。

次にガス圧を $p=30 \mathrm{kPa}$ に変えて放電の様子を撮影した。 $X=1 \mathrm{~mm}, 10.5 \mathrm{~mm}$ における放電の様子を図 10 に示す。どち らの背後電極幅においても $10 \mathrm{kPa}$ の放電の様子と比べ強い 発光が確認できるが, $30 \mathrm{kPa}$ においても沿面放電は必ず背後 電極幅の範囲内で生じた。

$X=10.5 \mathrm{~mm}$ の条件において各極性で撮影を 10 回行ったと きの発生の位置と回数を図 11 に示す。位置は導体の数と同 じ 9 分割し, 左から A〜I と記した。回数はその範囲で発生 した放電の回数を示す。背後電極の範囲内で生じるが, 放

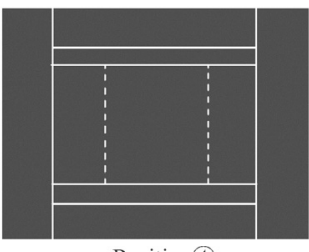

Positive (4)

$(V=0.84 \mathrm{kV} X=10.5 \mathrm{~mm}, p=30 \mathrm{kPa})$

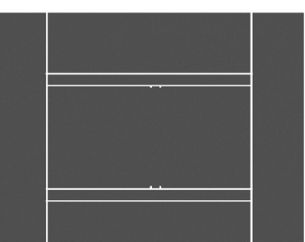

Positive(4)

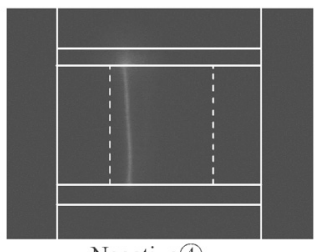

Negative (4)

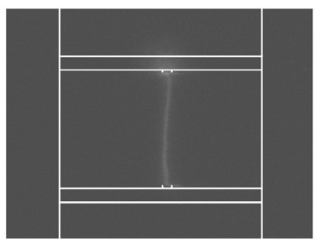

Negative(4)

$(V=0.88 \mathrm{kV} X=1 \mathrm{~mm}, p=30 \mathrm{kPa})$

Fig. 10. Picture of electrical discharg

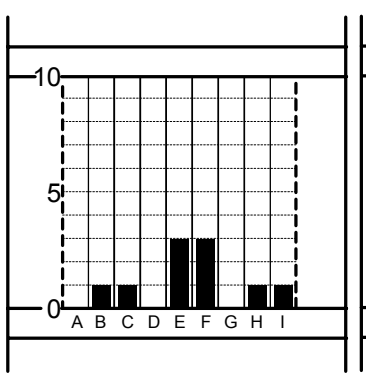

(a) Positive

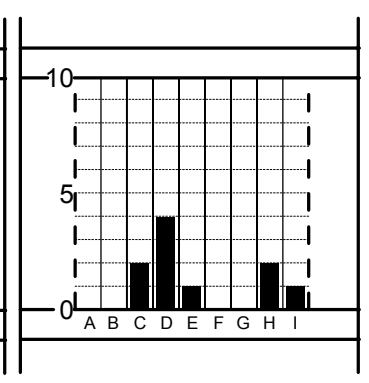

(b) Negative

Fig. 11. Position and probability of electrical discharge $(X=10.5 \mathrm{~mm}, p=60 \mathrm{kPa})$

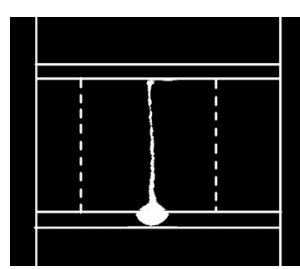

(a) Straight

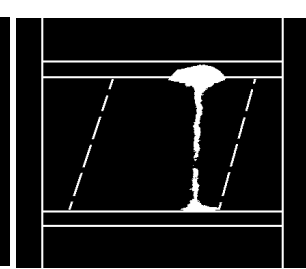

(b) Diagonal

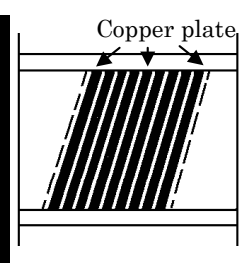

Fig. 12. Picture of electrical discharge for diagonal arrangement of back electrode $(X=10.5 \mathrm{~mm}, p=60 \mathrm{kPa})$ 


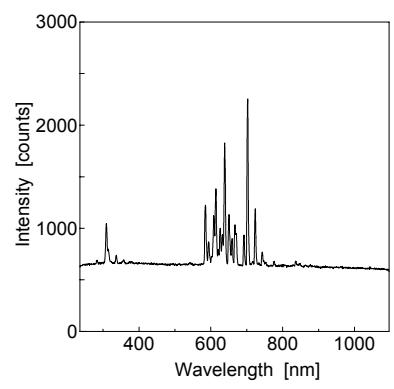

(a) $X=1 \mathrm{~mm}$ $(p=30 \mathrm{kPa}, V=0.62 \mathrm{kV})$

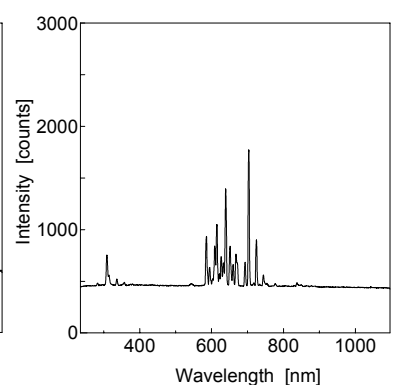

(b) $X=10.5 \mathrm{~mm}$ $(p=30 \mathrm{kPa}, V=0.62 \mathrm{kV})$

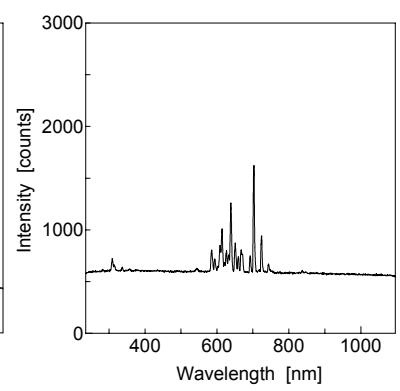

(c) $X=21 \mathrm{~mm}$ $(p=30 \mathrm{kPa}, V=0.54 \mathrm{kV})$

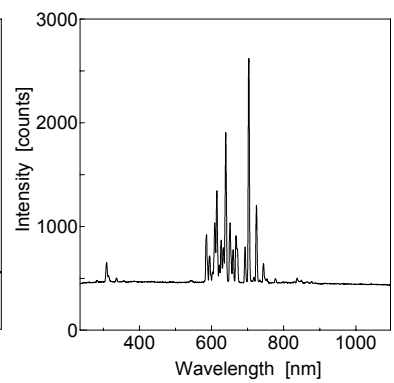

(d) $X=10.5 \mathrm{~mm}$ $(p=60 \mathrm{kPa}, V=0.64 \mathrm{kV})$

Fig. 13. Emission spectra of electrical discharge in Ne gas

電が同じ位置，特定の領域で発生することは認められな かった。これはガス圧に関係なくどの条件においても同様 の結果を示した。

次に, ガス圧が高いときに見られる放電が背後電極の影 響を受けた沿面放電であるか調べるため, 背後電極を電極 に対して斜めに配置し，そのときの放電の様子を図 12 に示 す。

放電開始電圧は電極に対して平行に置いた場合と同じで あったが，放電の様子はある点から放電が生じるとフラッ トケーブルの導体に沿って斜めに伸び，隣の導体に移りな がら，ギザギザの経路を通る。特にこれは，60kPaのとき顕 著に確認できた。

このようにフラットケーブルが放電路に影響を及ぼす結 果から背後電極を電極に対して垂直に配置した場合の放電 はフラットケーブルに沿って放電する沿面放電であると考 えられる。

〈3·3〉 発光スペクトルの解析 背後電極幅, ガス圧 の変化による放電のスペクトルの違いを調べるため，分光 器を用いて測定した。印加電圧の変化に伴ってスペクトル の強度も変化するため, 本実験では印加電圧は放電開始電 圧とした。図 13 に得られたスペクトルを示す。背後電極幅, ガス圧に関係なく, $300 \mathrm{~nm}$ 付近に 1,2 本の発光ピークと 580 〜 730nm に複数のピークが観測され，エネルギー準位の 3P から $3 \mathrm{~S}$ 一の遷移による発光である波長 $700 \mathrm{~nm}$ 付近が最も高 い強度を示した。背後電極幅の増大とともに発光強度は弱 くなり，またガス圧の上昇すると発光強度は強くなった。 前項で示した放電挙動は，フィルタの特性からみて，両波 長域の光によるものであるが，発光強度から考えて主に後 者の波長領域によるものといえ, 撮影された発光の強さと も対応している。

最も強い702nm の発光強度と背後電極幅の関係を図 14 に 示す。なお，バックグラウンド分は除去した。いずれのガ ス圧においても，背後電極幅の増加とともに発光強度は低 下した。また，ガス圧の上昇とともに強度も上昇すること がわかる。ガス圧が低い $10 \mathrm{kPa}$ では背後電極幅にほぼ均等 に広がる淡い赤色の放電，ガス圧を上げることにより濃淡 のある放電，赤い強く放電へと変化した目視観察結果と対 忘しているものといえる。

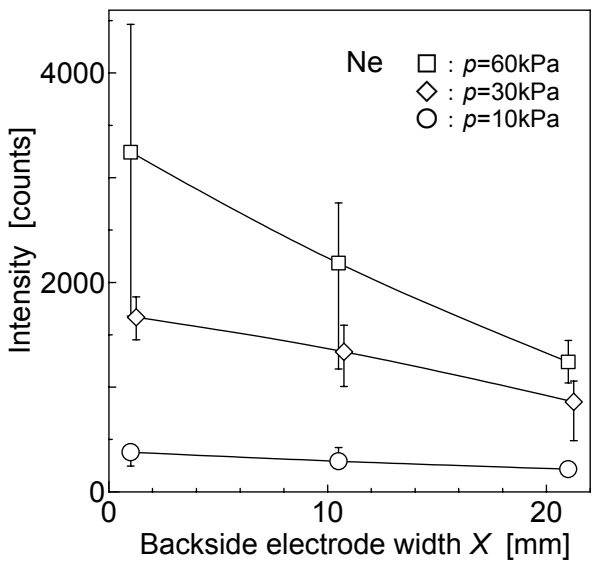

Fig. 14. Backside electrode width dependence of emission intensity

\section{4. 検 討}

ストライプ状背後電極を有した平板電極間の放電におけ る背後電極の影響について, 放電開始電圧, 放電の様子, 発光スペクトル解析の結果から考察する。交流電圧下での 背後電極を有する絶縁体表面では沿面放電が発生しやすい (2)といわれているように, 放電開始電圧は背後電極を配置す ることで, どの背後電極幅においても背後電極がないとき と比べて放電開始電圧は低下した。30kPa の場合で比較する と $X=1 \mathrm{~mm}$ では背後電極がない場合より約 $0.1 \mathrm{kV}$ 低下し, 背 後電極幅を広げることで放電開始電圧は徐々に低下し, $X=21 \mathrm{~mm}$ では約 $0.2 \mathrm{kV}$ 低下寸るという結果が得られた。これ は背後電極を配置した部分の電界が高電界になると考えら れ, 背後電極幅が拡がると背後電極内の導体部分が増え, 高電界領域が広くなり, 放電開始電圧に違いが出ると考え られる(11)。

また，どの背後電極幅においても $30 \mathrm{kPa}$ 辺りから放電開 始電圧が飽和の傾向を示した。これは図 5 の一眼レフカメ ラで撮影した側面の放電に見られるように， $30 \mathrm{kPa} ， 60 \mathrm{kPa}$ のとき背後電極に沿った放電となった。また, 絶縁物裏面 の背後電極の存在によって, 沿面放電が進展しやすくなる (2)(3) という報告から，ガス圧が $30 \mathrm{kPa}$ より高い場合，誘電体 に沿った放電となるため背後電極の影響が大きいと考えら 
れる。一方，ガス圧が低いとき放電路は沿面に沿わず，徐々 に背後電極から離れ, 弧を描くような放電となるため背後 電極の影響は少ない。このため，ガス圧が高くなると放電 開始電圧が飽和の傾向を示したと考えられる。

このように，電極間の最短を通らずに弧を描く放電は パッシェンミニマムの左側領域で見られるが，本実験の圧 力・放電ギャップ積值 $7.5 \mathrm{~cm} \cdot \mathrm{mmHg}$ から, パッシェンミニ マムの右側領域である。他の原因として, アーク放電が挙 げられるが，使用した実験回路では数十 $\mathrm{mA}$ と電流が低い ため, アーク放電で生じたとは考えにくい。このような現 象は沿面上の蓄積電荷によることも考えられるが, 今後さ らに研究を進める必要がある。

また放電が観測される位置，すなわち放電の発生位置は 必ず背後電極の範囲内であった。平行平板電極間の平等電 界と背後電極により高電界になりやすいためである。実際, 高電界が放電の発生に起因しているとの報告(6)などから, 本 実験条件においても背後電極の範囲で発生したと判断でき る。しかし, 誘電体表面に沿った放電が見られる $30 \mathrm{kPa}$, $60 \mathrm{kPa}$ での放電の様子(図 10, 図 12(a))に着目すると, 電極 間中央付近までは高圧電極からの放電路はわずかに歪んで あり, その後ほぼ直線的にアース電極に達していることが わかる。フラットケーブルの被覆等のため, 高圧電極側に おける放電発生位置を特定することはできないが, 背後電 極であるフラットケーブル内の導体は幅 $0.7 \mathrm{~mm}$, 厚さ $50 \mu \mathrm{m}$, ピッチ $1.0 \mathrm{~mm}$ (導体間隔 $0.3 \mathrm{~mm}$ )であり, 導体端部で電界集中 が生じるため, 端部上方に位置する高圧電極端で放電が発 生しやすい。発生した放電は導体端部に沿ってアース電極 へと進展していくが, 進展に伴い生じる空間電荷, 蓄積電 荷の影響によって, 導体端部の影響を受けにくくなる。そ の結果, 導体上部の沿面を進展するようになり, 放電路が 歪んだと考えられる。

さらに, 背後電極を斜めに配置した場合(図 12(b)), 沿面 放電は背後電極の導体端部あるいは導体に沿って電極間を 斜めに進展しようとする。しかし，写真の下方に配置され ている対向アース電極による鉛直方向の電界のが存在する とともに，導体間隔は $0.3 \mathrm{~mm}$ と狭くアース電極に近い隣接 導体端部の電界集中の影響を受ける。そのため, 隣接する 背後電極導体を飛び移る経路上の誘電体沿面を進展し, ギ ザギザ様の放電路を描いているものと考えられる。した がって，放電の進展は放電発生点に関係する導体だけでな $く$, 隣接する導体の影響も受ける。

スペクトル解析の結果からエネルギー準位の $3 \mathrm{P}$ から $3 \mathrm{~S}$ への遷移による波長 600〜 700nm 付近の発光が主として得 られた。また, ガス圧の上昇に伴う強度の増加, 背後電極 幅の増加に伴い強度低下が観測された。スペクトルの測定 は受光時間 $100 \mathrm{~ms}$ (6 周期に相当) でありこの間での放電発 生回数（放電電流パルス本数）にばらつきが生じている可 能性もある。しかし，100ms で 10 回の積算計測による実験 を 5 回実施してデータを得ており, 放電回数のバラつきの 影響は少ないものと考えられる。また, 用いた光ファイバ
の特性から直径約 $25 \mathrm{~mm}$ の領域の受光が可能であり, 電極 間全体からの放電発光を計測していると考えられる。通常, 発光は荷電粒子の再結合, 励起原子 - 分子の脱励起のエネ ルギー放出の一環として生じる。したがって, 発光強度は 荷電粒子, 励起原子 - 分子の数に関係していると考えられ る。放電開始時, 過電圧時ともに, 放電が生じた瞬間に放 電電流ピークが観測され, いずれの極性においても, 多数 の放電電流ピークの発生は観測されなかった。そこで, 背 後電極幅 $X=21 \mathrm{~mm}$, ガス圧 $10 \mathrm{kPa}$ の放電開始時の放電電流 のピーク值は約 $30 \mathrm{~mA}, 30 \mathrm{kPa}$ では 2 倍の約 $60 \mathrm{~mA}, 60 \mathrm{kPa}$ では 2.5 倍の $75 \mathrm{~mA}$ の電流となった。このことからも, 発光 強度は放電電流と関係していることを示唆している。

一方, 背後電極を狭めた場合, 発光強度は増加した。す でに述べたように, 背後電極の導体端部での電界集中の影 響により導体端部上の誘電体と高圧電極の接する点あるい はその近傍で放電が発生する確率が高くなると考えられ る。すなわち背後電極幅を狭めることで背後電極内の導体 数が少なくなり, 放電が発生する確率の高い領域も限定さ れる。そのため, 陰極点の移動が少なく, 同じ位置から放 電する確率が高くなる。また, 発光強度と放電電流の関係 が示唆されていることから, 放電発生位置の制限によって 放電電流が変化し, 上述のような発光強度の背後電極幅依 存性が現れた可能性もある。しかし, 現段階ではその原因 は不明であり, ストライプ状背後電極系での電界分布, 放 電発生位置, 放電電流等の詳細な検討が必要である。

\section{5. まとめ}

$\mathrm{Ne}$ ガス中における, 複数の銅馢導体のフラットケーブル によるストライプ状背後電極を有した平板電極間の沿面放 電と発光を調べた結果を以下にまとめる。

（1）背後電極を有する場合の放電開始電圧は背後電極 がない場合に比べて低下し, 背後電極幅が最も大きい $21 \mathrm{~mm}$ において放電開始電圧は最も低くなった。これは, 背後電 極のを配置すること, 背後電極幅の増大に従い, 導体が増 えるため, 高電界領域が拡がることで説明できる。また, 放電開始電圧のガス圧依存性において, 背後電極がない場 合，放電開始電圧はガス圧の上昇に伴い単調に増大したが， 背後電極が存在する場合, $30 \mathrm{kPa}$ を越えると, ほぼ一定の值 となった。

(2) 光学的な観測によって, 放電は必ず背後電極の存在 する範囲内で生じたが, 特定の位置, 領域での発生は認め られなかった。背後電極内の導体による高電界領域の存在, 特に導体端部における電界集中の影響が関係しているもの といえる。また, 斜めに背後電極導体が配置された場合, 沿面放電は隣接導体を飛び移るようなギザギザ状の放電路 が観測された。このことは, 沿面放電に対しては, 背後電 極は平板電極付近での放電の発生だけでなく, 放電進展路 に対しても影響すること, 隣接する背後電極導体の影響も 存在することを示している。

（3）放電による発光のスペクトル解析から, $580 \mathrm{~nm}$ から 
$720 \mathrm{~nm}$ の波長域の発光が観測された。また，700nm 付近の 発光が最も強い。この発光の強度は, 背後電極幅の増大と ともに低下し, 背後電極幅一定の条件下ではガス圧の上昇 とともに発光強度は増大した。また, 発光強度は放電電流 と関係していることが示唆されたが，不明な点も多く今後 さらに検討が必要である。

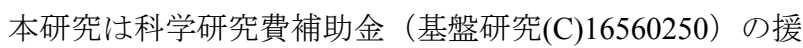
助を受けて実施された。

(平成 18 年 2 月 24 日受付, 平成 18 年 6 月 16 日再受付)

\section{文献}

(1) 電気学会放電ハンドブック出版委員会編：「放電ハンドブック(上 卷)」, p.315, オーム社 (1998)

(2) Y. Yamano, Y. Takahashi, and S. Kobayashi : "Influence of Barrier on AC Flashover Strength of Insulator with Back Electrode", T. IEE Japan., Vol.109-A, No.5, pp.211-218 (1989-5) (in Japanese) 山野芳昭・高橋雄造・小林繁雄 : 「背後電極をもつ絶縁物の交流沿面 絶縁耐力に及ぼすバリアの影響」,電学論 A， 109，5，pp.211-218 (1989-5)

(3) 大小正路 :「沿面放電における背後電極および表面電荷の役割」静電 学誌, Vol.15, pp.191-197 (1991)

(4) M. Endo, T. Sato, S. Sato, and T. Sakakibara : "Propagation Characteristics of a Rectilinearly Channeled Negative Surface", T. IEE Japan, Vol.115-A, No.9, pp.845-850 (1995-9) (in Japanese) 遠藤正雄・佐藤敏郎・佐藤重範・榊原 剛 : 「負極性直線状沿面放電 の進展特性」, 電学論 A, 115, 9, pp.845-850 (1995-9)

(5) H. Hama, K. Inami, H. Fujii, T. Ooishi, M. Yoshimura, and K. Nakanishi : "Leader Formation and Propagation of Positive Surface Discharges at Impulse Voltage in $\mathrm{SF}_{6} \mathrm{Gas} "$, T. IEE Japan, Vol.114-A, No.5, pp.397-406 (1994-5) (in Japanese)

羽馬洋之・井波 潔・藤井治久・大石貴之・吉村 学・仲西幸一郎： $\left\lceil\mathrm{SF}_{6}\right.$ ガス中正極性沿面放電のリーダの発生と進展」, 電学論 $\mathrm{A}, \mathbf{1 1 4}$, 5, pp.397-406 (1994-5)

(6) T. Ohkubo and Y. Nomoto : "Recent Ozone Generation Technologies by Discharge-Induced Plasmas", J. Inst. Electrostatic Japan, Vol.19, pp.369-374 (1995) (in Japanese)

大久保利一・野本幸治：「放電プラズマによる最近のオゾン発生技 術」, 静電学誌, 19, pp.369-374 (1995)

(7) K. Wani : "DC-type Plasma Displays", J. IEE Japan, Vol.116, No.8, p.153 (1996-8) (in Japanese)

和迩浩一:「DC プラズマディスプレイ」, 電学誌, 116, 8, p.513 (1996-8)
(8) T. Yoshioka : "Discharge and Ultraviolet Radiation for Plasma displays", $J$. IEE Japan, Vol.116, p.509 (1996) (in Japanese)

吉岡俊博 : 「プラズマディスプレイの放電と紫外線発光」, 電学誌, 116, p.509 (1996)

（9）「プラズマディスプレイ内の放電基礎特性」，電学会技術報告書， 688, p.72 (1998)

(10) 菊池雄二 ・鈴木宏明 - 遠藤正雄「低気圧における平面状放電の進展 現象」, 放電研究, 153, p.35 (1996)

(11) M. Ohki and S. Saito : "Barrier Effect on Surface Discharge in Air", T.IEE Japan, Vol.108A, pp.351-358 (1988) (in Japanese)

大木正路・斉藤 茂:「気中沿面放電におけるバリア効果」, 電学論, 108-A, pp.351-358 (1988)

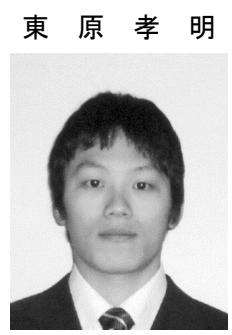

（学生員） 1982 年 6 月 14 日生。 2005 年 3 月姫 路工業大学電気工学科卒業。同年 4 月兵庫県立 大学大学院工学研究科博士前期課程電気系工 学専攻入学, 現在に至る。2005 年電気関係学会 関西支部連合大会奨励賞受賞。

上 野 秀 樹 (正員) 1960 年 10 月 2 日生。1985 年 3 月信

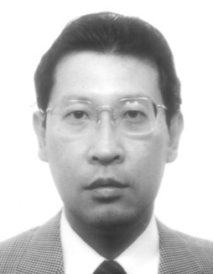
州大学大学院工学研究科修士課程修了。1988 年 3 月大阪大学大学院工学研究科博士後期課程 修了。同年 4 月住友電気工業(株)入社。1997 年 10 月姫路工業大学工学部電気工学科助教授, 2004 年 4 月兵庫県立大学大学院助教授, 現在に 至る。2004 年〜2005 年ドイツ・アーヘン工科 大学高電圧技術研究所訪問研究員。主として,

複合絶縁，沿面放電，部分放電に関する研究に従事。工学博士。

中 山 博 史 (正員) 1943 年 3 月 14 日生。 1965 年 3 月姫

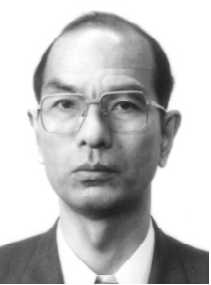
路工業大学電気工学科卒業。1991 年 10 月同大 学工学部電気工学科教授, 1998 年 4 月から 2 年間同大学学生部長兼任。2004 年 4 月兵庫県立 大学大学院教授, 現在に至る。主として, 気体 および固体誘電体の絶縁破壊に関する研究に 従事。工学博士。 